Research Article

Joanna Orzet*

\title{
From imagination to political reality? The Grand Duchy of Lithuania as a successor of Rome in the early modern historiography $\left(15^{\text {th }}-18^{\text {th }} \text { centuries }\right)^{\#}$
}

https://doi.org/10.1515/openps-2018-0015

received December 17, 2018; accepted December 31, 2018.

\begin{abstract}
At the beginning of the Renaissance Lithuanians understood that to join the civilization of Western Europe, it was necessary to have an appropriate (it means: very long) tradition. Like other countries, they had to create their own myth of origin. The most prestigious tradition was Greek-Roman antiquity, so the country's origin story was invented, claiming its people descended directly from Rome. According to subsequent chronicles, the founder of the new state was Palemon (Publius Libon, initially Vilia).

Using the theory of cultural memory of Jan and Aleida Assmann, the article presents how and why the Lithuanian myth of origin was transformed from $15^{\text {th }}$ to the end of the $18^{\text {th }}$ century. Particular attention was paid to the current needs of the state and the powerful noble families of the Grand Duchy of Lithuania, which also found their origins in the state myth.

During the early modern period, the changes in the story were made (including the date of Palemon's arrival in the Lithuanian lands). Nonetheless, the myth was not questioned for a long time. Even once it had already been established that it was no more than a fairy tale, the story was revived again, performing other functions in the $19^{\text {th }}$ century.
\end{abstract}

Keywords: cultural memory; foundation myth; mythical genealogy; Palemon; the Grand Duchy of Lithuania; PolishLithuanian historiography; Greco-Roman antiquity in early modern period.

\section{Introduction}

The Late Middle Ages and Early Modern Period was a period of particular importance for Lithuania. Relations between Lithuania, further: the Grand Duchy of Lithuania, and Western Europe were getting stronger - in the political, economic, cultural and religious spheres. From the end of the $14^{\text {th }}$ century to the beginning of the $16^{\text {th }}$ century the socio-political system of the Grand Duchy of Lithuania was formed. From 1385 it was connected thanks to the personal union with the Kingdom of Poland. In the following years, integration between these two states was strengthened. The Kingdom of Poland was the most important intermediary in contacts between the Grand Duchy of Lithuania and Western Europe ${ }^{1}$.

1 J. Kiaupienė, A. Zakrzewski, Unie polsko-litewskie - próba nowego spojrzenia, In: A. Jankiewicz (Ed.), Lex est Rex in Polonia et in Lithuania... Tradycje prawno-ustrojowe Rzeczypospolitej - doświadczenie i dziedzictwo, Biuro Trybunału Konstytucyjnego, Warszawa, 2008, 65-82.

\footnotetext{
*Corresponding author: Joanna Orzet, Institute of History, Faculty of Philosophy and History, University of Lodz, A. Kamińskiego 27 a, $90-219$ tódź, E-mail: joanna.orzel@interia.eu

\# This article is based on my previous publications about the Lithuanian founding myth: J. Orzet, Historia - tradycja - mit w pamięci kulturowej szlachty Rzeczypospolitej w XVI-XVIII wieku, Muzeum Pałacu Króla Jana III w Wilanowie, Warszawa, 2016; eadem, Poszukiwanie rodowodu Rzeczypospolitej Obojga Narodów przez autora Skarbca rozmaitych sciencyi..., In: W. Walczak, K. Łopatecki (Eds.), Stan badań nad wielokulturowym dziedzictwem dawnej Rzeczypospolitej, vol. 7, Instytut Badań nad Dziedzictwem Kulturowym Europy, Białystok, 2017, 389-414; eadem, Lech i Palemon - mityczni założyciele Królestwa Polskiego i Wielkiego Księstwa Litewskiego, In: J. Tazbir, S. Zagórski (Eds.), Z szablą i z kielichem, czyli życie po sarmacku, Oficyna Wydawnicza „Stopka”, Łomża, 2015, 23-39.
} 
The real union signed between these two countries in 1569 in Lublin was the crowning achievement towards maintaining good relations between these states ${ }^{2}$. In this way, the Polish-Lithuanian Commonwealth was formed.

In the period between these two unions (1385-1569) and after the Union of Lublin, the Grand Duchy of Lithuania attempted to emphasize its belonging to Latin civilization. Claiming to originate from historical, preferably ancient ancestors combined with biblical motifs could put the Lithuanian state's image on par with the long tradition boasted by Western European countries ${ }^{3}$. Italian cities $^{4}$, France ${ }^{5}$ and England ${ }^{6}$ found their predecessors in mythological Troy, Polish medieval chroniclers mentioned Lech as the founder of Poland, who lived in the Early Middle Ages ${ }^{7}$. As Artūras Tereškinas stated, "The Renaissance Europe was obsessed with the genealogy related to the cult of the heroic past: the descent, pretended or real, from illustrious ancestors was seen as promising fame and glory"8. Wanting to join the Western European civilization, the Lithuanians had to create a political myth about their origins.

Their situation was complicated. For the Grand Duchy of Lithuania medieval times meant, on the one hand, wars (mainly with the Teutonic Order), on the other hand - lack of historical written tradition, a different language, undeveloped education, but most of all, no need for state genealogy. In the $16^{\text {th }}$ century, however, the state's past turned out to be very important - to emphasize the country's place among the Western, and not Eastern civilizations. The threat from Ruthenia was not only military, but also religious and cultural. Equally important was the rivalry with the Kingdom of Poland to emphasize Lithuania's antiquity, to continue towards an even closer integration with the Kingdom of Poland - as equals ${ }^{9}$. Rimvydas Petrauskas stated that so far researchers have been searching for the

2 L. Glemža, R. Šmigelskytė-Stukienè (Eds.), Liublino unija: idẻja ir jos tęstinumas / Unia lubelska: idea i jej kontynuacja, Nacionalinis muzjejus Lietuvos Didžiosios Kunigaikštystes valdovu rumai, Vilnius, 2011.

3 Cf. A. Borst, Der Turmbau von Babel. Geschichte der Meinungen über Ursprung und Vielfalt der Sprachen und Völker, Vol. 1-4, Hiersemann, Stuttgart, 1957-1963; G. Melville, Troja. Die integrative Wiege europäischer Mächte im ausgehenden Mittelalter, In: F. Seibt, W. Eberhard (Eds.), Europa 1500. Integrationsprozesse im Widerstreit. Staaten, Regionen, Personenverbände, Christenheit, Klett-Cotta, Stuttgart, 1987, 415-532; K. Wulf, Troja - Metamorphosen eines Mythos. Französische, englische und italienische Überlieferungen des 12. Jahrhunderts im Vergleich, Akademie Verlag, Berlin, 2009; P.J. Geary, The Myth of Nations. The Medieval Origins of Europe, Princeton University Press, Princeton (N.J.), 2002; G. Huppert, The Idea of perfect history. Historical erudition and historical philosophy in Renaissance France, Urbana, University of Illinois Press, Chicago, London, 1970, 25-28; K. Pomian, Przeszłość jako przedmiot wiary. Historia i filozofia w myśli średniowiecza, $2^{\text {nd }}$ ed., Wydawnictwo Uniwersytetu Warszawskiego, Warszawa, 2009.

4 A. Grandazzi, La Troie rêvée des Romains: quelles leçons pour l'Europe contemporaine?, In: B. Bernabé, O. Camy (Eds.), Le mythes de fondation et l'Europe, Éditions Universitaires de Dijon, Dijon, 2013, 37-53.

5 Cf. C. Beaune, Naissance de la nation France, Gallimard, Paris 1985; P. Morawski, Mit o trojańskim pochodzeniu Franków w historiografii średniowiecznej Francji, Przegląd Humanistyczny, 2007, 51, no. 5, 55-70; P. Cohen, In Search of the Trojan Origins of French: The Uses of History in the Elevation of the Vernacular in Early Modern France, In: A. Shepard, S.D. Powell (Eds.), Fantasies of Troy. Classical Tales and the Social Imaginary in Medieval and Early Modern Europe, Centre for Reformation and Renaissance Studies, Toronto, 2004, 63-80; M.-B. Bruguière, Mythes de fondation et mission de la France: la légende troyenne, In: M. Ganzen (Ed.), L'influence de l'antiquité sur la pensée politique européenne (XVI-XXème siècles), Presses universitaires d’Aix-Marseille, Aix-en-Provence, 1996, 51-75; A. Bossuat, Les origines troyennes: leur rôle dans la littérature historique au XVe siècle, Annales de Normandie, 1958, 8, no. 2, 187-197; K. Pomian, Francs et Gaulois, In: P. Nora (Ed.), Les Lieux de mémoire, vol. 2, Quarto Gallimard, Paris, 1997, 2245-2300; B.L.O. Richter, Trojan or Merovingians? The Renaissance Debate over the Historical Origins of France, In: Mèlanges a la mémoire de Franco Simone, Vol. 4, Slatkine, Geneve, 1983, 111-134; G. Huppert, The Trojan Franks and Their Critics, Studies in the Renaissance, 1965, 12, 227-241, DOI: 10.2307/2857076; C.-G. Dubois, „Nos ancêtres les Gaulois”. Le développement d'un mythe des origines nationales au 16 $6^{\mathrm{e}}$ siècle, In: P. Viallaneix, J. Ehrard (Eds.), Nos ancêtres les Gaulois, Faculté des Lettres et Sciences Humaines de l'Université de Clermont-Ferrand II, Clermont-Ferrand, 1982, 18-35; R.E. Asher, National Myth in Renaissance France. Francus, Samothes and the Druids, Edinburgh University Press, Edinburgh, 1993.

6 Cf. A. Adolph, Brutus of Troy And the Quest for the Ancestry of the British, Pen \& Sword Family History, South Yorshire [UK], 2015; T.D. Kendrick, British Antiquity, Barnes \& Noble, Methuen, New York, London, 1970; A. Branny, Trojanie i król Artur w angielskiej świadomości historycznej do XVIII wieku, Historyka. Studia Metodologiczne, 1986, 16, 3-20.

7 In the $16^{\text {th }}$ century the date of Lech's arrival to Polish lands was specified - it was 550. From Bernard Wapowski's chronicle until the end of $18^{\text {th }}$ century almost all writers from the Polish-Lithuanian Commonwealth did not oppose this date. More about Lech see in: J. Orzeł, Historia - tradycja - mit..., 27-69.

8 A. Tereškinas, The imperfect body of the community. Identity, discourse and nation in the seventeenth-century Grand Duchy of Lithuania, Lietuviu literaturo sir tautosakos institutas, Vilnius, 2005, 254.

9 Some researchers underline that the foundation myth was anti-Polish, some that anti-Moscovian. Cf. J. Jakubowski, Studya nad stosunkami narodowościowemi na Litwie przed Unią Lubelską, nakładem Towarzystwa Naukowego Warszawskiego, Warszawa, 1912; J. Suchocki, Geneza litewskiej legendy etnogenetycznej. Aspekty polityczne i narodowe, Zapiski Historyczne, 1987, 52, no. 1, 27-67; E. Kulicka, Legenda o rzymskim pochodzeniu Litwinów i jej stosunek do mitu sarmackiego, Przegląd Historyczny, 1980, 71, no. 1, 7, 20; M. Zachara-Wawrzyńczyk, Geneza 
influence or creators of the Lithuanian founding myth and have underlined too strongly the political significance of the story ${ }^{10}$. Creating the foundation myth in order to compete with other countries' origin stories was, however, of less importance than the fact that it led to a birth of a historical consciousness in Lithuania - the most important component in the development of the national structure ${ }^{11}$.

A myth has two functions: the foundational and contra-present. The former is legitimised by the contemporary social system and political order through reference to the past. The latter recalls its memory, but from the present day's perspective, underlining what is now missing. Contemporaneity entails the necessity to verify the myth, to change its elements. Aleida and Jan Assmann refer to the power of updating the myth as the mythomotor. Cultural memory perceives history from the perspective of the present day: events from myths are vivid, but reconstructed depending on what is important or needed in the present situation ${ }^{12}$. In cultural memory, facts are not important; what is fundamental is remembered history, which converts into a myth thanks to tradition. The article will present how chroniclers and other historical writers constructed the Lithuanian founding myth and how and why it changed from the $15^{\text {th }}$ century to the end of the $18^{\text {th }}$ century.

\section{The backgrounds of the political myth}

Jan Długosz (1415-1480) played an extremely important role in the first stage of popularization ${ }^{13}$ of the Lithuanian state myth. According to his Annals or Chronologies of the Illustrious Kingdom of Poland (written from 1455 until the death of the author in 1480), prince Vilia was the founder of the country that later became the Grand Duchy of Lithuania. In 39 or $38 \mathrm{BC}$ he had to leave Rome as a follower of Pompey, who was defeated in the struggle for power by Julius Caesar ${ }^{14}$. Vilia took with him his family and 500 comrades with their relatives. This group allowed him to quickly settle Lithuanian lands. As Artūras Vasiliauskas noted, the number 500 is a symbol of citizens' opposition to despotism - the Athenian boule (a council of 500 citizens) opposed Peisistratos' tyranny in the $6^{\text {th }}$ century $\mathrm{BC}^{15}$. There was a symbol of opposition to dictatorship and glorification of people's rule. After arriving in the Lithuanian land, Vilia founded the city - Romnove, as a reference to the Eternal City: Roma novae, new Rome. The city was quickly renamed to Vilnius - in honour of the commander (similarly to Rome in honour of Romulus and Remus, or Paris in honour of the eponymous prince of Troy). The name of the new state was also supposed to be a reference to the country's Roman heritage: the letter "L" was added to "Italia" and in this way name Lithalia (then: Litualia, then: Lithuania) was created ${ }^{16}$. According to Długosz, the Lithuanian language also had Roman origins - it was referred to as "rotten Latin". In this way, many references to the Greco-Roman antiquity were created, motifs of the sources of Western European civilization. Lithuanians became heirs of the ancient (especially) Roman tradition and were included in the Western world, Latin civilization, and Europe. The theory of Roman origin has contributed to the consolidation of Lithuanian consciousness ${ }^{17}$. The foreign origin of the founder of the state was to add splendour to Lithuanians, as was the case of Trojan origin of European countries ${ }^{18}$.

legendy o rzymskim pochodzeniu Litwinów, Zeszyty Historyczne. Uniwersytet Warszawski, 1963, 3, 15; M. Kosman, Litwa pierwotna. Mity, legendy, fakty, Iskry, Warszawa, 1989, 176-177.

10 R. Petrauskas, Europa późnego średniowiecza a rozwój społeczeństwa i kultury Wielkiego Księstwa Litewskiego, Zapiski Historyczne, 2013, 78, no. 3, 44.

11 J. Suchocki, Geneza litewskiej legendy..., 36.

12 About cultural memory see: J. Assmann, Pamięć kulturowa. Pismo, zapamiętywanie i polityczna tożsamość w cywilizacjach starożytnych, trans. A. Kryczyńska-Pham, ed. R. Traba, Warszawa, Wydawnictwo Uniwersytetu Warszawskiego, 2008; A. Assmann, Między historią a pamięcią. Antologia, ed. M. Saryusz-Wolska, Warszawa, Wydawnictwo Uniwersytetu Warszawskiego, 2013.

13 Długosz documented a circulating tale, he did not invent this story. M. Niendorf, Wielkie Księstwo Litewskie. Studia nad kształtowaniem się narodu u progu epoki nowożytnej (1569-1795), trans. M. Grzywacz, Wydawnictwo Poznańskie, Poznań, 2011, 77.

14 J. Długosz, Roczniki czyli Kroniki sławnego Królestwa Polskiego. Księga dziesiąta 1370-1405, ed. Z. Perzanowski, ed. Latin text D. Turkowska, M. Kowalczyk, trans. J. Mrukówna, Państwowe Wydawnictwo Naukowe, Warszawa, 1981, 215, $218-219$.

15 A. Vasiliauskas, Antyk i sarmatyzm, trans. B. Kalęba, In: Kultura Wielkiego Księstwa Litewskiego. Analizy i obrazy, ed. V. Ališauskas [et al.], trans. P. Bukowiec, B. Kalęba, B. Piasecka, Towarzystwo Autorów i Wydawców Prac Naukowych Universitas, Kraków, $2006,6$.

16 J. Długosz, Roczniki..., 216.

17 J. Jakubowski, Studya nad stosunkami narodowościowemi..., 34.

18 M. Kosman, Litwa pierwotna..., 171. 
Długosz's theses were accepted by another chronicler - Maciej Miechowita (1457-1523). In his Descriptio Sarmatiarum Asianae et Europianae (1521) he agreed to call Lithuania Litalia, and the fact that names Vilnius comes from Vilia. Miechowita even stated that after the seizure of Lithuania and Samogitia, Vilia's comrades called the tribe who had lived there Italian people ${ }^{19}$.

Ruthenian manuscripts from the $15^{\text {th }}$ and $16^{\text {th }}$ century played an extremely important role in the development of Lithuanian etnogenetic myth. There were three version of these chronicles: the short Chronicle of the Grand Dukes of Lithuania (1420s), the Chronicle of The Grand Duchy of Lithuania and Samogitia (first half of $16^{\text {th }}$ century) and the Bychowiec Chronicle. The story of the beginnings of Lithuania in these chronicles has changed: "With regards to the subjects described, clearly they are the ones relevant to the political interests of the regents mainly with regards to disputes with neighbouring countries" ${ }^{20}$. In the first chronicle there was no mention of the Lithuanian origin. In the second work there was a change in the time and circumstances of Palemon's leaving Rome. Who was Palemon? He was a mythical founder of Lithuania; author of the Chronicle of The Grand Duchy of Lithuania and Samogitia changed his name - from Vilia to Palemon (Publius Libon). In Greek mythology, Palemon is the name of a deity caring for sailors. Lithuanian ancestors went from Rome to new lands during the reign of Nero (not Julius Caesar). Such a chronological change was of considerable importance. Who left the lands of the Roman Empire during the reign of Nero? Probably Christians, which made Lithuanian feel more predestined to feel a part of the Latin, Western, Christian Europe. The biblical and Roman motifs were combined ${ }^{21}$. Palemon arrived in Lithuania by sea in A.D. 57. From the mouth of Neman River, Palemon got through with his followers (the number 500 remained unchanged). The new state was named - after the second part of Publius Libon - Libonia, further: Livonia.

Who were the Palemon's comrades? He held Column (Latin: Colonna) as his coat of arms. The ancestors of Centaur, Ursyn, and Rose coats of arms came with him. The Gediminids and Jagiellonians (a princely and royal family) and the Gasztołds descended from the Column family. When there were no Columns, the Centaurs ruled - the Holszański and the Giedroyć families. The Ursyn family gave rise to the family of Downojno, while Roses - to the family of Moniwid ${ }^{22}$. These families certainly influenced the development of the founding story, it is possible that they were also some of its inspirers ${ }^{23}$. The Radziwiłł family are missing among them, but soon they will try to join to this prestigious group. Several families comprising the social elite of the Grand Duchy of Lithuania appropriated the myth of Roman origin ${ }^{24}$.

In the Bychowiec Chronicle ${ }^{25}$ the date of Palemon's journey and arrival in the Lithuanian lands was changed to the time of Attila the Hun (445-453). Probably someone pointed out that the time between the arrival of Palemon in Lithuania and the first real rulers was too long. Jan Jurkiewicz emphasized that in this chronicle we could see a miniature of the society of the Grand Duchy of Lithuania from $16^{\text {th }}$ century: prince and his subjects - nobility and common people ${ }^{26}$. Thus, the myth had a national character in terms of language, customs and tradition of Lithuania, but also explained social relations in this state at that time.

The theory about the Roman origin of Lithuanians provoked disputes between scholars in the $16^{\text {th }}$ century. Italian Filippo Buonaccorsi (1437-1496) opposed this theory - he noticed the differences between the languages and religious

19 Maciej z Miechowa, Opis Sarmacji Azjatyckiej i Europejskiej, introduction H. Barycz, trans. T. Bieńkowski, Zakład Narodowy im. Ossolińskich, Wydawnictwo PAN, Wrocław 1972, 64.

20 M. Bonda, History of Lithuanian Historiography. Didactical guidelines, Vytatuas Magnus University, Kaunas, $2013,49$.

21 A. Vasiliauskas, Antyk i sarmatyzm..., 4. See also: R. Petrauskas, Dziejopisarstwo a świadomość historyczna, trans. B. Kalęba, In: Kultura Wielkiego Księstwa Litewskiego..., 201-213.

22 J. Suchocki, Geneza litewskiej legendy..., 41; J. Jurkiewicz, Od Palemona do Giedymina. Wczesnonowożytne wyobrażenia o początkach Litwy, cz. 1, W kręgu latopisów litewskich, Wydawnictwo Naukowe Uniwersytetu im. Adama Mickiewicza, Poznań, 2012, 59, 90-112. About these noble families see: R. Petrauskas, Palemon und die vier Sippen: die römische Abstammungstheorie der Litauer, In: S. Doncecker (Ed.), Abstammungsmythen und Völkergenealogien im frühneuzeitlichen Ostseeraum, Greifswald [in press].

23 “[...] it is possible that the recent versions [of Lithuanian chronicles - J.O.] are more representative of the magnates' positions” - M. Bonda, History of Lithuanian Historography..., 49. See also: J. Suchocki, Geneza litewskiej legendy..., 41.

24 E. Semenowicz, Wokół genealogii Litwinów. U źródeł mitu i sporu historyczno-kulturowego, Studia z Dziejów Rosji i Europy ŚrodkowoWschodniej, 2011, 46, 19-20, DOI: 10.12775/SDR.2011.01; A. Tereškinas, The imperfect body..., 272-282.

25 About Bychowiec Chronicle see: J. Ochmański, Nad Kroniką Bychowca, Studia Źródłoznawcze, 1967, 12, 155-163; J. Jakubowski, Studya nad stosunkami narodowościowemi..., 57; O. Łatyszonek, Polityczne aspekty przedstawienia średniowiecznych dziejów ziem białoruskich w historiografii Wielkiego Księstwa Litewskiego XV-XVI w., Białoruskie Zeszyty Historyczne, 2006, 25, 20; Z. Kiaupa, J. Kiaupienė, A. Kuncevičius, Historia Litwy. Od czasów najdawniejszych do 1795 roku, trans. P. Grablunas [et al.], Wydawnictwo Naukowe PWN, Warszawa 2007, $190-193$. 26 J. Jurkiewicz, Od Palemona do Giedymina..., 61-62. 
customs of the two nations ${ }^{27}$. However, he could have created the character of Palemon ${ }^{28}$. One of the greatest historical authorities, Marcin Kromer (1512-1589), stated that after the war between Caesar and Pompey, a group of Romans came to Lithuania to settle down and establish a new state. They took the name of the Livons from Libon - their leader ${ }^{29}$. This scholar also recorded the name of the mythical founder of Lithuania - in his work it was Libon ${ }^{30}$. At the end of the $16^{\text {th }}$ century, when Kromer was writing his chronicle, he already knew the works of Maciej Stryjkowski (more about him in the subsequent parts of article) and they could have changed his point of view about the beginnings of Lithuania ${ }^{31}$. Another scholar, Marcin Bielski (1495-1575), also had a problem with Palemon. In his chronicle (published in 1564) he doubted the Roman origin of Lithuanians ${ }^{32}$. However, in the next edition of his work, published in 1597 by his son Joachim, there was information that the founder of the state was Italian ${ }^{33}$. Certainly, Stryjkowski's works also influenced the change in the decision on the reality of Palemon. In 1564 Conversation of a Pole with a Lithuanian - the work created by Augustinus Rotundus (1520-1582) - was published. It was a polemic with Stanisław Orzechowski's (1513-1586) work Quincunx. Rotundus sought to emphasize the equality between Poland and Lithuanian - shortly before the Union of Lublin (1569). The Lithuanian character of the book states that his nation wants to be equal to Poles, wants to be free ${ }^{34}$. Conversation was published anonymously and its goal was to express the opinion of the entire Lithuanian nation ${ }^{35}$. Rotundus deciphered the abbreviation P. before Libon's name as Publius, mistakenly - according to the writer - called Palemon ${ }^{36}$. Rotundus, on the basis of Ruthenian manuscripts, distinguished the Jagiellonian dynasty, supposedly stemming from Witenes - the ancestor of the Column coat of arms, who in turn was a descendant of Palemon ${ }^{37}$. The Jagiellonian dynasty was presumed to have an ancient origin, a tradition that was of great importance not only for the Lithuanian, but also for the Polish nation. The dynasty of ancient origin added prestige to the entire Polish-Lithuanian state.

In contrast to the above-mentioned writers, Alexander Guagnini (1538-1614) presented a different version of the beginnings of Lithuania. After Jan Długosz, Maciej Miechowita and Ruthenian manuscripts, Guagnini stated that Roman nobility with the Italian prince Palemon arrived in the Lithuanian lands. He gave three reasons for Palemon's escape appearing in the literature: Nero's tyranny, deserved banishment or escape from Attila's cruelty. Guagnini mentioned the noble families who came with Palemon, giving the coats of arms, which gave rise to the most prominent Lithuanian families ${ }^{38}$. According to Guagnini, Palemon arrived in the Lithuanian land and conquered the society settled there - common people, who, according to him, came from the Goths ${ }^{39}$. In his version the myth has underlying antiRussian sentiment - Guagnini recalled that a small Lithuanian nation was under the rule of Ruthenia ${ }^{40}$. The arrival of Palemon was seen as salvation - an acquisition of independence and an incorporation into the group of states of Latin civilization, Western Europe.

27 More: O. Łatyszonek, Polityczne aspekty..., 10-11.

28 Ibidem, 12.

29 M. Kromer, Kronika polska Marcina Kromera biskupa warmińskiego ksiąg XXX, dotąd w trzech językach, a mianowicie w łacińskim, polskim i niemieckim wydana, na język polski z łacińskiego przełożona przez Marcina z Błażowa Błażowskiego i wydana w Krakowie w drukarni M. Loba r. 1611, vol. 1, druk i nakład K. Pollak, Sanok, 1857, 128.

30 See: I. Lewandowski, Florus w Polsce, Archiwum Filologiczne, vol. 26, Zakład Narodowy im. Ossolińskich, Wrocław, $1970,75$.

31 About the history of the Grand Duchy of Lithuania in Kromer's work and about the reasons for changing his point of view see: H.-J. Bömelburg, Polska myśl historyczna a humanistyczna historia narodowa (1500-1700), trans. Z. Owczarek, introduction A. Lawaty, Towarzystwo Autorów i Wydawców Prac Naukowych Universitas, Kraków, 2011, 200-203.

32 E. Kulicka, Legenda o rzymskim pochodzeniu..., 11-12.

33 M. Bielski, Kronika polska Marcina Bielskiego, vol. 1, ed. K.J. Turowski, druk i nakład K. Pollak, Sanok, 1856, 252.

34 A. Rotundus Mieleski, Rozmowa Polaka z Litwinem, trans. E. Buszewicz, In: K. Koehler (Ed.), Stanisława Orzechowskiego i Augustyna Rotundusa debata o Rzeczypospolitej, Wyższa Szkoła Filozoficzno-Pedagogiczna „Ignatianum”, Wydawnictwo WAM, Kraków, $2009,149$.

35 M. Baryczowa, Augustyn Rotundus Mieleski - pierwszy historyk i apologeta Litwy, In: W. Voisé (Ed.), Z dziejów polskiej kultury umysłowej w XVI i XVII wieku, Zakład Narodowy im. Ossolińskich, Wydawnictwo PAN, Wrocław, 1976, 119; more about Conversation see: ibidem, 117-132. 36 A. Rotundus Mieleski, Rozmowa Polaka..., 211-214.

37 Ibidem.

38 A. Gwagnin, Kronika Sarmacyey Europskiey, w ktorey się zamyka Krolestwo Polskie ze wszystkiemi państwy, xięstwy, y prowincyami swemi: tudzież też Wielkie Księstwo Litewskie, Ruskie, Pruskie, Zmudzkie, Inflantskie, Moskiewskie, y część Tatarow, trans. M. Paszkowski, In: Zbior dziejopisow polskich we czterech tomach zawarty, vol. 4, w Drukarni J.K. Mci y Rzeczypospolitey u XX Sociestatis Jesu, Warszawa, $1768,222-223$.

39 Ibidem.

40 Ibidem, s. 223. 


\section{Maciej Stryjkowski and his role in creating historical consciousness of Lithuanians}

Maciej Stryjkowski (c. 1547 - c. 1593) was the most significant propagator of the idea of the Roman origin of Lithuanians, whose works had the greatest significance for the political culture of Lithuania and historical awareness of Lithuanians ${ }^{41}$. In his works he emphasized the figure of Palemon, who came from Italy. The best "souvenir" of him were the coats of arms, which existed in the time of Palemon. In Stryjkowski's chronicle (1582) he extended the description of the common people living in the Lithuanian lands before Palemon's arrival. They supposed to be simple, without rights, without power, free and dissolute, extremely different from the Italians who arrived. This, however, did not prevent them from uniting and creating one state ${ }^{42}$. It is worth noting Stryjkowski's earlier work - On the Genesis, Descent, Courage, and Valiant Endeavours of the Lithuanians, Samogitians, and Ruthenians (1577) ${ }^{43}$. The third chapter of this book is a description of the beginnings of Lithuania and is dedicated to the Radziwiłł family - it was a family that had not yet appeared among the ancient noblemen who came with Palemon. The myth of the Roman origin could have been written by Stryjkowski for the sake of this great magnate family - after all he dedicated his works to Radziwilł family’s members and they were often mentioned on the pages of his chronicle ${ }^{44}$.

Stryjkowski not only summed up the previously mentioned motifs in historiography, but also exalted Palemon, inserting him into the motifs known from the Greco-Roman antiquity. For the chronicler, it was no surprise that Palemon had sailed to the Lithuanian lands. He compared Lithuanian's founder to Jason, who commanded the expedition for the Golden Fleece ${ }^{45}$. Palemon appears to be the defender of his people - this was to be the main reason for his journey to the north ${ }^{46}$. Taking his comrades with him, Palemon deserves to be compared to Aeneas escaping from Troy ${ }^{47}$. During his journey, the gods promised the dreamer Palemon a reward for his and his people's misfortunes - not only new lands abundant in food and forests, but also Palemon was to create a glorious, valiant state ${ }^{48}$. Although the scholar synonymously used the names: Palemon and P. Libon (Publius Libon), the name Palemon survived in further historiography and manuscripts. Until the end of the $18^{\text {th }}$ century Stryjkowski's chronicles were the most popular historical works on the Lithuanian and Ruthenian territories as the culmination of the Renaissance historiography of the Lithuanian nation, the history of the Lithuanian ethnos ${ }^{49}$. Lithuanians owed the writer the popularization of the ancient history of Lithuania, inscribed in world history, including Christian (in this tradition Lithuanians were also grandchildren of Noah, and Palemon - like him - also had three sons). The chronicler also included Lithuanian genealogy in the Sarmatian myth ${ }^{50}$. As Darius Kuolys noted, "This model of Sarmatism emphasizes not the past, but the community of present and future, the national and civic self-awareness of Lithuania connected with the general Sarmatian consciousness, without denying or violating Lithuanian identity" ${ }^{51}$. It united the multi-ethnic nobility of the

41 R. Petruaskas, Europa późnego średniowiecza..., 6. See more: Z. Wojtkowiak, Maciej Stryjkowski, dziejopis Wielkiego Księstwa Litewskiego. Kalendarium życia i działalności, Poznań, Uniwersytet im. Adama Mickiewicza, 1990; Ch. Watson, Tradition and Translation. Maciej Stryjkowski’s Polish Chronicle in Seventeenth-Century Russian Manuscripts, Uppsala Universitet, Västerås, 2012.

42 M. Stryjkowski, Kronika polska, litewska, żmódzka i wszystkiej Rusi Macieja Stryjkowskiego, vol. 1, introduction M. Malinowski, I. Daniłowicz, nakład Gustawa Leona Glüksberga, Księgarza, Warszawa, 1846, 78.

43 Idem, O początkach, wywodach, dzielnościach, sprawach rycerskich i domowych sławnego narodu litewskiego, żemojdzkiego i ruskiego, przedtym nigdy od żadnego ani kuszone, ani opisane, z natchnienia Bożego a uprzejmie pilnego doświadczenia, ed. J. Radziszewska, trans. M. Ściebora [et al.], ed. A. Jelicz, Warszawa, Państwowy Instytut Wydawniczy, 1978, 57.

44 J. Bardach, Kronika Macieja Stryjkowskiego i jej rozpowszechnienie w Rosji (w związku z książką A.I. Rogowa), Przegląd Historyczny, 1967, 58, no. 2, 327. About the Radziwiłł family see especially: M. Antoniewicz, Protoplaści książąt Radziwiłłów. Dzieje mitu i meandry historiografii, DiG, Warszawa, 2011.

45 M. Stryjkowski, Kronika polska..., 70.

46 Ibidem, 74-75; idem, O początkach..., 57.

47 Idem, Kronika polska..., 77, 78.

48 Idem, O początkach..., 60.

49 D. Kuolys, Asmuo, tauta, valstybė. Lietuvos Didžiosios Kunigaikštystės istorinèje literatūroje. Renesansas ir barokas, Mokslo ir Enciklopediju Leidykla, Vilnius 1992, 265.

50 About the Sarmatian myth see: J. Orzeł, Historia - tradycja - mit... (there further literature).

51 D. Kuolys, Sarmatyzm a piśmiennictwo barokowe Wielkiego Księstwa Litewskiego, Barok. Historia, Literatura, Sztuka, 1996, 2, 150. Cf. L. Lubamersky, National self-perception among the Lithuanian nobility: Evidence from the Radziwiłł family, Journal of Baltic Studies, 2001, 32, 
Grand Duchy of Lithuania in the $16^{\text {th }}$ century into Lithuanian nationality. The growing sense of national pride among Lithuanians contributed to the crystallization and popularization of the myth of Palemon, a myth of origin from the Romans. Thanks to their own myth of origin, Lithuanians did not need Polish mediation in order to demonstrate their belonging to the Western culture ${ }^{52}$.

\section{Between tradition and Enlightenment}

The next import chronicle for Lithuanian historiography was the work of Albert Wijuk Kojałowicz (1609-1677) - History of Lithuania (the first part was published in 1650, the second - 1669). This author repeated, after Maciej Stryjkowski, information about Palemon (P. Libon), his various reasons for escaping from Italy, taking with him representatives of the nobility, and about the coats of arms mentioned above. Kojałowicz, however, changed the date of Palemon's arrival in Lithuanian lands to $924^{53}$. In Kojałowicz's armorial he repeated his view of Palemon ${ }^{54}$. This meant the beginnings of the Lithuanian nation was later than that of Poles (550). Lithuanian society was not outraged by this. It seems that the story of the ancient Palemon as a founder of Lithuania lost its political significance in the second half of the $17^{\text {th }}$ century ${ }^{55}$. Kojałowicz chose a more credible version, although the myth was not questioned. History of Lithuania was a textbook for the learning history and rhetoric ${ }^{56}$, and even as a basis for creating the plot of Jesuit dramas - students playing in the performances were called "the youth of Palemon and Gediminas" 57 . Palemon was directly adjacent to Gediminas, for Lithuanians there was no difference between imaginary ancestors and real rulers, all of them belonged to the past.

In the $18^{\text {th }}$ century literature writers continued to present an image of ancient Lithuanian origin. The date of Palemon's arrival in Lithuania (after 929) was pushed back by Kasper Niesiecki (1682-1744) in his armorial ${ }^{58}$. Józef Andrzej Załuski (1702-1774) approached Palemon, listing him in his catalogue of Lithuanian rulers, but also in the $10^{\text {th }}$ century, not earlier ${ }^{59}$. Władysław Aleksander Łubieński (1703-1767) repeated that Palemon had come from Italy with families, e.g.: Ursyn, Column, Julian, Gasztołd, Scypion, Pac, etc. ${ }^{60}$ Interestingly, not only coats of arms were mentioned, but also specific families - in this case, Pac family, who were considered to be "victims" in the previous armorials (their ancient origin not being mentioned) ${ }^{61}$.

The author of the first Polish-language encyclopedia - Benedykt Chmielowski (1700-1763) listed three reasons why Italian Palemon escaped Italy. The writer presented most of the motifs appearing in historiography. According to him, Palemon came to the Lithuanian lands with other noble families (with their coasts of arms). Their arrival prompted the local community, supported by Palemon, to resist the Ruthenians, who had been ruling in these lands with cruelty,

no. 1, 5-18, DOI: 10.1080/01629770000000211; S. Donecker, Origines Livonorum. Frühneuzeitliche Hypothesen zur Herkunft der Ersten und Letten, Böhlau Verlag, Köln, Weimar, Wien, 2017, 70-71.

52 M. Cetwiński, M. Derwich, Herby, legendy, dawne mity, Krajowa Agencja Wydawnicza, Wrocław, 1989, 19.

53 A. Wijuk Kojałowicz, Historiae litvanae pars prior, de rebvs litvanorum ante susceptam christianam religionem, conjunctionemque Magni Litvaniae Ducatus cum Regno Poloniae libri novem [...], part 1, nakład Georg Förster, Dantisci 1650, 31.

54 Idem, Herbarz rycerstwa W.X. Litewskiego tak zwany Compendium czyli O klejnotach albo herbach których familie stanu rycerskiego w prowincyach Wielkiego Xięstwa Litewskiego zażywają, wydanie „Herolda polskiego”, Kraków, 1897, 2.

55 A. Vasiliauskas, Antyk i sarmatyzm..., 14.

56 K. Puchowski, Edukacja historyczna w jezuickich kolegiach Rzeczypospolitej 1565-1773, Wydawnictwo Uniwersytetu Gdańskiego, Gdańsk, 1999, 82-92.

57 D. Kuolys, Sarmatyzm..., 146.

58 K. Niesiecki, Korona polska Korona polska przy zlotey wolnosci starożytnemi wszystkich kathedr, prowincyi y rycerstwa kleynotami heroicznym męstwem y odwagą, naywyższemi honorami; a naypierwey cnotą, pobożnością, y swiątobliwością ozdobiona potomnym zaś wiekom na zaszczyt y nieśmiertelna sławe pamietnych w tey oyczyznie synow podana, vol. 1, part 1, W Drukarnii Collegium Lwowskiego Societatis JESU, Lwów, 1728, 9.

59 J.A. Załuski, Cała Polska za zloty to jest opisanie Polski trojakie [...], National Library of Poland, Manuscripts Department, 3209/II, 5v. 60 W. Łubieński, Swiat we wszystkich swoich częsciach większych y mnieyszych to iest: w Europie, Azyi, Affryce y Ameryce [...] geograficznie, chronologicznie y historycznie okryslony, vol. 1, do Druku Wrocławskiey W Sląsku Akademii Sociestatis Jesu [...] Podany, Wrocław, $1740,435$. 61 See more: A. Baniulytė, Pacai ar „Pazzi”? Nauja Palemono legendos versija LDK raštijoje, Senoji Lietuvos Literatūra, 2004, 18, 140-166. 
and expel them from their territories ${ }^{62}$. The arrival of Palemon was a time of liberation, the rejection of the Ruthenian yoke thanks to the new leader. Lithuanian's nearest neighbor, Ruthenia, was its most dangerous rival. Unlike Guagnini, who described the homage paid to the Ruthenian dukes, Chmielowski emphasized the independence of Lithuania in the past. Considering the Russian Empire's aspiration in the $18^{\text {th }}$ century to have more and more influence also in the Polish-Lithuanian Commonwealth, the writer's statement was very current.

In the middle of $18^{\text {th }}$ century Józef Aleksander Jabłonowski (1711-1777) presented all the opinions about Palemon and came to the conclusion that he could not exist. The proof was the lack of records in ancient materials about the Palemon, and especially about 500 representatives of the nobility leaving Rome. The writer also drew attention to the multiplicity of the names of the mythical ruler, which should lead to doubts about his existence. The sailing to the Lithuanian coast was also uncertain ${ }^{63}$. This was the first case of questioning the story about the Roman origin of Lithuanians.

Stanisław Józef Duńczewski (1701-1767) in his armorial emphasized that the Column coast of arms comes from the reign of Palemon, who had arrived in Lithuania from Italy ${ }^{64}$. Duńczewski postponed the date of Palemon's arrival until around $990^{65}$. According to the writer, Palemon and his comrades arrived by sea with their wives and army, some of them settled in Lithuania and some in Samogitia. They quickly became friends with the settled society and united. When the former ruler died, Palemon was elected (without any opposition) by the entire community (including common people) as Lithuanian and Samogitian prince ${ }^{66}$. The free election, the well-known and practiced way of electing a ruler from the Polish-Lithuanian Commonwealth, was sanctioned by tradition.

In the $18^{\text {th }}$ century historical writers presented two camps - the continuators of the foundation myth and its critics. The best example is Ewaryst Andrzej Kuropatnicki (1734-1788). In his armorial he quoted Jabłonowski - Palemon could not exist. Nevertheless, in further part of his work Kuropatnicki presented the chronology rulers: he started with Palemon, mentioning 373 as the beginning of his reign ${ }^{67}$.

Mečislovas Jučas noted that August Ludwig Schlözer (1735-1809), and then Joachim Lelewel (1786-1861) questioned the story of Palemon ${ }^{68}$. The researcher did not mention Adam Naruszewicz (1733-1796), who also did not believe in the "fairy tale about Palemon" 69 . However, the story of Palemon did not end there. In $19^{\text {th }}$ century Teodor Narbutt (17841864) and Dionysius Paszkiewicz (1764-1830) recognized Palemon as a historical figure. This testifies to the persistence of the myth about Roman origin of Lithuanians ${ }^{70}$. As Tomas Venclova stated, especially at the beginning of the $19^{\text {th }}$ century this myth influenced the process of shaping of the Lithuanian nation (in the modern meaning) ${ }^{71}$.

62 B. Chmielowski, Nowe Ateny, albo Akademia wszelkiey scyencyi pełna, na rozne tytuły iak na classes podzielona, mądrym dla memoryału, idiotom dla nauki, politykom dla praktyki, melancholikom dla rozrywki erygowana, part 2, drukarnia Pawła Józefa Golczewskiego, Lwów, 1746, 292.

63 J.A. Jabłonowski, Heraldica: to iest osada kleinotow rycerskich i wiadomość znaków herbownych dotąd w Polszcze nie obiaśniona [...], w Drukarnii J.K.M Coll. Soc. Iesu, Lwów, 1752, 149.

64 S.J. Duńczewski, Herbarz wielu domow Korony Polskiey y W. X. Litewskiego, dla niezupełnego opisania, albo opuszczenia, y wielu odmiennosci nieprzyzwoitych, za dawnych y poznieyszych autorow, herby z rodowitoscią wyrazaiących, nie mało dotąt ukrzywdzonych, zebraniem wielu familii we dwa tomy, częsciami rzeczone [...], vol. 1, Drukarnia Akademii Zamojskiej, [Zamość], 1757, 324-325.

65 Ibidem, s. 328.

66 Ibidem.

67 E.A. Kuropatnicki, Wiadomość o kleynocie szlacheckim, oraz herbach domów szlacheckich w Koronie Polskiey i Wielkim Księstwie Litewskim, tudzież w przyległych prowincyach [...], part 4, druk M. Gröll, Warszawa, 1789, 3.

68 M. Jučas, Legenda o rzymskim pochodzeniu Litwinów, Przegląd Wschodni, 1997, 4, no. 2, 292.

69 A.S. Naruszewicz, Noty do księgi pierwszey, In: Kaia Korneliusza Tacyta dzieła wszystkie, vol. 3, trans. A.S. Naruszewicz, w Drukarnii J.K.M Coll. Soc. Iesu, Warszawa, 1804, 5.

70 E. Kulicka, Legenda o rzymskim pochodzeniu..., 1; M. Kosman, Litwa pierwotna..., 199, 202.

71 T. Venclova, Mit o początku, trans. R. Śliwowski, Teksty. Teoria Literatury, Krytyka, Interpretacja, 1974, 4, 111-116. See more: M. LitwinowiczDroździel, O starożytnościach litewskich. Mitologizacja historii w XIX-wiecznym piśmiennictwie byłego Wielkiego Księstwa Litewskiego, Towarzystwo Autorów i Wydawców Prac Naukowych Universitas, Kraków, 2008. 


\section{Conclusion}

Palemon existed in the cultural memory, historical awareness, because Lithuanians needed an ancient heritage. Depending on the needs, various motifs from mythical story were recalled. During the reign of the Jagiellons it was mentioned by those who were aware of Lithuanian identity and wanted to protect it. Unions with Poles liberated in Lithuanians a sense of otherness and a desire for independence. At the same time Lithuanians wanted to be a part of the Western civilization without the participation of Poles. A fundamental role was played by Maciej Stryjkowski, who reconciled the Sarmatian and Lithuanian myths. The chronicler set himself two goals: to demonstrate equality in the origin of Polish and Lithuanian nobility, but also to satisfy the ambitions of great Lithuanian families. Thanks to Stryjkowski, the myth of the Roman origin of Lithuanians spread quickly. The need to create its own history and the dynamic development of separateness had a real impact on the consciousness of the nobility of the Lithuanian lands.

Memory about the past has an identity function - it unites people who identify themselves with the same myth, refer to it, transfer the values and attitudes contained in it onto future generations. The factors of the native culture are: origin, historical tradition, religion and language ${ }^{72}$ - jointly they consolidate national consciousness. The genealogical myth of origin was crystalised - Lithuania had its ancestor Palemon: "The awareness of a glorious and long history, ancient parables evoked a sense of national pride, the conviction of a common genesis facilitated the unification processes" ${ }^{\text {"3 }}$.

The story of Palemon was to, on the one hand, sanction and distinguish the Lithuanian nation historically younger than the Polish one, as well as to confirm the community, belonging to the Latin culture, and on the other hand, to emphasize the civilizational and cultural superiority of this nation in comparison with the Kingdom of Poland and Ruthenia. Eugenija Ulčinaitė summarized that Lithuanian magnates wanted to confirm their dignity, and the myth was an argument in the fight for political independence from powerful neighbours: Moscow, Livonia, and Poland ${ }^{74}$. The sense of pride in a longer tradition, separation from the influence of the Moscow state allowed the Lithuanian nation to feel exalted.

The postponed date of Palemon's arrival in Lithuanian lands to the $10^{\text {th }}$ century did not provoke a big discussion. Palemon fulfilled his function in the $16^{\text {th }}$ century - when he reminded the nation about the rights of the Lithuanian nobility entering into a real union with Poles. And in this form the story of the Palemon was repeated until the $19^{\text {th }}$ century.

\section{Bibliography}

\section{Manuscript sources}

Załuski J.A., Cała Polska za zloty to jest opisanie Polski trojakie [...], National Library of Poland, Manuscripts Department, 3209/II.

\section{Printed sources}

Bielski M., Kronika polska Marcina Bielskiego, vol. 1, ed. K.J. Turowski, druk i nakład K. Pollak, Sanok, 1856.

Chmielowski B., Nowe Ateny, albo Akademia wszelkiey scyencyi pełna, na rozne tytuły iak na classes podzielona, mądrym dla memoryału, idiotom dla nauki, politykom dla praktyki, melancholikom dla rozrywki erygowana, part 2, drukarnia Pawła Józefa Golczewskiego, Lwów, 1746 .

72 J. Kłoczowski, Europa słowiańska w XIV-XV wieku, Państwowy Instytut Wydawniczy, Warszawa, 1984, s. 313.

73 E. Kulicka, Legenda o rzymskim pochodzeniu..., 7.

74 E. Ulčinaitė, Literatura neołacińska jako świadectwo litewskiej świadomości państwowej i narodowej, In: J. Axer (Ed.), Łacina w Polsce, part 1-2, Między Slavia Latina i Slavia Orthodoxa, Ośrodek Badań nad Tradycją Antyczną w Polsce i w Europie Środkowo-Wschodniej, Uniwersytet Warszawski, Warszawa, 1995, s. 32. Cf. A. Semjančuk, Rolya rymskay legendy y̆ farmavanni dzyarzhay̆nay idealogii Vyalikaga Knyastva Litoy̆skaga, Białoruskie Zeszyty Historyczne, 2002, 18, 178-184; D.M. Althoen, That Noble Quest: From True Nobility to Enlightened Society in the Polish-Lithuanian Commonwealth, 1550-1830, vol. 1, A dissertation submitted in partial fulfillment of the requirements for the degree of Doctor of Philosophy (History) in the University of Michigan 2000, passim. 
Długosz J., Roczniki czyli Kroniki sławnego Królestwa Polskiego. Księga dziesiąta 1370-1405, ed. Z. Perzanowski, ed. Latin text D. Turkowska, M. Kowalczyk, trans. J. Mrukówna, Państwowe Wydawnictwo Naukowe, Warszawa, 1981.

Duńczewski S.J., Herbarz wielu domow Korony Polskiey y W. X. Litewskiego, dla niezupetnego opisania, albo opuszczenia, y wielu odmiennosci nieprzyzwoitych, za dawnych y poznieyszych autorow, herby z rodowitoscią wyrazaiących, nie mato dotąt ukrzywdzonych, zebraniem wielu familii we dwa tomy, częsciami rzeczone [...], vol. 1, Drukarnia Akademii Zamojskiej, [Zamość], 1757.

Gwagnin A., Kronika Sarmacyey Europskiey, w ktorey się zamyka Krolestwo Polskie ze wszystkiemi państwy, xięstwy, y prowincyami swemi: tudzież też Wielkie Księstwo Litewskie, Ruskie, Pruskie, Zmudzkie, Inflantskie, Moskiewskie, y część Tatarow, trans. M. Paszkowski, In: Zbior dziejopisow polskich we czterech tomach zawarty, vol. 4, w Drukarni J.K. Mci y Rzeczypospolitey u XX Sociestatis Jesu, Warszawa, 1768 .

Jabłonowski J.A., Heraldica: to iest osada kleinotow rycerskich i wiadomość znaków herbownych dotąd w Polszcze nie obiaśniona [...], w Drukarnii J.K.M Coll. Soc. lesu, Lwów, 1752.

Kromer M., Kronika polska Marcina Kromera biskupa warmińskiego ksiąg XXX, dotąd w trzech językach, a mianowicie w tacińskim, polskim i niemieckim wydana, na język polski z łacińskiego przełożona przez Marcina z Błażowa Błażowskiego i wydana w Krakowie w drukarni M. Loba r. 1611, t. 1, druk i nakład K. Pollak, Sanok, 1857.

Kuropatnicki E.A., Wiadomość o kleynocie szlacheckim, oraz herbach dom.w szlacheckich w Koronie Polskiey i Wielkim Księstwie Litewskim, tudzież w przyległych prowincyach [...], part 4, druk M. Gröll, Warszawa, 1789.

Łubieński W., Swiat we wszystkich swoich częsciach większych y mnieyszych to iest: w Europie, Azyi, Affryce y Ameryce [...] geograficznie, chronologicznie y historycznie okryslony, vol. 1, do Druku Wrocławskiey W Sląsku Akademii Sociestatis Jesu [...] Podany, Wrocław, 1740.

Maciej z Miechowa, Opis Sarmacji Azjatyckiej i Europejskiej, introduction H. Barycz, trans. T. Bieńkowski, Zakład Narodowy im. Ossolińskich, Wydawnictwo PAN, Wrocław 1972.

Naruszewicz A.S., Noty do księgi pierwszey, In: Kaia Korneliusza Tacyta dzieła wszystkie, vol. 3, trans. A.S. Naruszewicz, w Drukarnii J.K.M Coll. Soc. lesu, Warszawa, 1804.

Niesiecki K., Korona polska Korona polska przy zlotey wolnosci starożytnemi wszystkich kathedr, prowincyi y rycerstwa kleynotami heroicznym męstwem y odwagą, naywyższemi honorami; a naypierwey cnotą, pobożnością, y swiątobliwością ozdobiona potomnym zaś wiekom na zaszczyt y nieśmiertelna sławe pamietnych w tey oyczyznie synow podana, vol. 1, part 1, W Drukarnii Collegium Lwowskiego Societatis JESU, Lwów, 1728,

Rotundus Mieleski A., Rozmowa Polaka z Litwinem, trans. E. Buszewicz, In: K. Koehler (Ed.), Stanisława Orzechowskiego i Augustyna Rotundusa debata o Rzeczypospolitej, Wyższa Szkoła Filozoficzno-Pedagogiczna „Ignatianum”, Wydawnictwo WAM, Kraków, 2009.

Stryjkowski M., Kronika polska, litewska, żmódzka i wszystkiej Rusi Macieja Stryjkowskiego, vol. 1, introduction M. Malinowski, I. Danitowicz, nakład Gustawa Leona Glüksberga, Księgarza, Warszawa, 1846.

Stryjkowski M., O początkach, wywodach, dzielnościach, sprawach rycerskich i domowych sławnego narodu litewskiego, żemojdzkiego i ruskiego, przedtym nigdy od żadnego ani kuszone, ani opisane, z natchnienia Bożego a uprzejmie pilnego doświadczenia, ed. J. Radziszewska, trans. M. Ściebora [et al.], ed. A. Jelicz, Warszawa, Państwowy Instytut Wydawniczy, 1978.

Wijuk Kojałowicz A., Historiae litvanae pars prior, de rebvs litvanorum ante susceptam christianam religionem, conjunctionemque Magni Litvaniae Ducatus cum Regno Poloniae libri novem [...], part 1, nakład Georg Förster, Dantisci 1650.

Wijuk Kojałowicz A., Herbarz rycerstwa W.X. Litewskiego tak zwany Compendium czyli O klejnotach albo herbach których familie stanu rycerskiego w prowincyach Wielkiego Xięstwa Litewskiego zażywają, wydanie „Herolda polskiego”, Kraków, 1897.

\section{Studies}

Adolph A., Brutus of Troy And the Quest for the Ancestry of the British, Pen \& Sword Family History, South Yorshire [UK], 2015.

Althoen D.M., That Noble Quest: From True Nobility to Enlightened Society in the Polish-Lithuanian Commonwealth, 1550-1830, vol. 1, A dissertation submitted in partial fulfillment of the requirements for the degree of Doctor of Philosophy (History) in the University of Michigan 2000.

Antoniewicz M., Protoplaści książąt Radziwittów. Dzieje mitu i meandry historiografii, DiG, Warszawa, 2011.

Asher R.E., National Myth in Renaissance France. Francus, Samothes and the Druids, Edinburgh University Press, Edinburgh, 1993.

Assmann J., Pamięć kulturowa. Pismo, zapamiętywanie i polityczna tożsamość w cywilizacjach starożytnych, trans. A. Kryczyńska-Pham, ed.

R. Traba, Warszawa, Wydawnictwo Uniwersytetu Warszawskiego, 2008.

Assmann A., Między historią a pamięcią. Antologia, ed. M. Saryusz-Wolska, Warszawa, Wydawnictwo Uniwersytetu Warszawskiego, 2013.

Baniulytė A., Pacai ar „Pazzi”? Nauja Palemono legendos versija LDK raštijoje, Senoji Lietuvos Literatūra, 2004, 18, 140-166.

Bardach J., Kronika Macieja Stryjkowskiego i jej rozpowszechnienie w Rosji (w związku z książką A.I. Rogowa), Przegląd Historyczny, 1967, 58, no. 2, 326-336.

Baryczowa M., Augustyn Rotundus Mieleski - pierwszy historyk i apologeta Litwy, In: W. Voisé (Ed.), Z dziejów polskiej kultury umysłowej w XVI i XVII wieku, Zakład Narodowy im. Ossolińskich, Wydawnictwo PAN, Wrocław, 1976.

Beaune C., Naissance de la nation France, Gallimard, Paris 1985.

Bonda M., History of Lithuanian Historiography. Didactical guidelines, Vytatuas Magnus University, Kaunas, 2013.

Borst A., Der Turmbau von Babel. Geschichte der Meinungen über Ursprung und Vielfalt der Sprachen und Völker, Vol. 1-4, Hiersemann, Stuttgart, 1957-1963. 
Bossuat A., Les origines troyennes: leur rôle dans la littérature historique au XVe siècle, Annales de Normandie, 1958, 8, no. 2, $187-197$. Bömelburg H.-J., Polska myśl historyczna a humanistyczna historia narodowa (1500-1700), trans. Z. Owczarek, introduction A. Lawaty, Towarzystwo Autorów i Wydawców Prac Naukowych Universitas, Kraków, 2011.

Branny A., Trojanie i król Artur w angielskiej świadomości historycznej do XVIII wieku, Historyka. Studia Metodologiczne, 1986, 16, 3-20. Bruguière M.-B., Mythes de fondation et mission de la France: la légende troyenne, In: M. Ganzen (Ed.), L'influence de l'antiquité sur la pensée politique européenne (XVI-XXème siècles), Presses universitaires d’Aix-Marseille, Aix-en-Provence, 1996, 51-75.

Cetwiński M., Derwich M., Herby, legendy, dawne mity, Krajowa Agencja Wydawnicza, Wrocław 1989.

Cohen B., In Search of the Trojan Origins of French: The Uses of History in the Elevation of the Vernacular in Early Modern France, In: A. Shepard, S.D. Powell (Eds.), Fantasies of Troy. Classical Tales and the Social Imaginary in Medieval and Early Modern Europe, Centre for Reformation and Renaissance Studies, Toronto, 2004, 63-80.

Donecker S., Origines Livonorum. Frühneuzeitliche Hypothesen zur Herkunft der Ersten und Letten, Böhlau Verlag, Köln, Weimar, Wien, 2017.

Dubois C.-G., "Nos ancêtres les Gaulois". Le développement d'un mythe des origines nationales au 16e siècle, In: P. Viallaneix, J. Ehrard (Eds.), Nos ancêtres les Gaulois, Faculté des Lettres et Sciences Humaines de l'Université de Clermont-Ferrand II, Clermont-Ferrand, 1982, 18-35.

Geary P.J., The Myth of Nations. The Medieval Origins of Europe, Princeton University Press, Princeton (N.J.), 2002.

Glemža L., Šmigelskytè-Stukienė R. (Eds.), Liublino unija: idèja ir jos tęstinumas / Unia lubelska: idea i jej kontynuacja, Nacionalinis muzjejus Lietuvos Didžiosios Kunigaikštystes valdovu rumai, Vilnius, 2011.

Grandazzi A., La Troie rêvée des Romains: quelles leçons pour l'Europe contemporaine?, In: B. Bernabé, O. Camy (Eds.), Le mythes de fondation et l'Europe, Éditions Universitaires de Dijon, Dijon, 2013, 37-53.

Huppert G., The Idea of perfect history. Historical erudition and historical philosophy in Renaissance France, Urbana, University of Illinois Press, Chicago, London, 1970.

Huppert G., The Trojan Franks and Their Critics, Studies in the Renaissance, 1965, 12, 227-241, DOI: 10.2307/2857076.

Jakubowski J., Studya nad stosunkami narodowościowemi na Litwie przed Unią Lubelską, nakładem Towarzystwa Naukowego Warszawskiego, Warszawa, 1912.

Jučas M., Legenda o rzymskim pochodzeniu Litwinów, Przegląd Wschodni, 1997, 4, no. 2, 289-297.

Jurkiewicz, Od Palemona do Giedymina. Wczesnonowożytne wyobrażenia o początkach Litwy, cz. 1, W kręgu latopisów litewskich, Wydawnictwo Naukowe Uniwersytetu im. Adama Mickiewicza, Poznań, 2012.

Kendrick T.D., British Antiquity, Barnes \& Noble, Methuen, New York, London, 1970.

Kiaupa Z., Kiaupienė J., Kuncevičius A., Historia Litwy. Od czasów najdawniejszych do 1795 roku, trans. P. Grablunas [et al.], Wydawnictwo Naukowe PWN, Warszawa 2007.

Kiaupienė J., Zakrzewski A., Unie polsko-litewskie - próba nowego spojrzenia, In: A. Jankiewicz (Ed.), Lex est Rex in Polonia et in Lithuania... Tradycje prawno-ustrojowe Rzeczypospolitej - doświadczenie i dziedzictwo, Biuro Trybunału Konstytucyjnego, Warszawa, 2008, 65-82.

Kłoczowski, Europa słowiańska w XIV-XV wieku, Państwowy Instytut Wydawniczy, Warszawa, 1984.

Kosman M., Litwa pierwotna. Mity, legendy, fakty, Iskry, Warszawa, 1989.

Kulicka E., Legenda o rzymskim pochodzeniu Litwinów i jej stosunek do mitu sarmackiego, Przegląd Historyczny, 1980, 71, no. 1, 1-21.

Kuolys D., Asmuo, tauta, valstybė. Lietuvos Didžiosios Kunigaikštystės istorinėje literatūroje. Renesansas ir barokas, Mokslo ir Enciklopediju Leidykla, Vilnius 1992.

Kuolys, Sarmatyzm a piśmiennictwo barokowe Wielkiego Księstwa Litewskiego, Barok. Historia, Literatura, Sztuka, 1996, 2, 141-153. Lewandowski I., Florus w Polsce, Archiwum Filologiczne, vol. 26, Zakład Narodowy im. Ossolińskich, Wrocław, 1970.

Litwinowicz-Droździel M., O starożytnościach litewskich. Mitologizacja historii w XIX-wiecznym piśmiennictwie byłego Wielkiego Księstwa Litewskiego, Towarzystwo Autorów i Wydawców Prac Naukowych Universitas, Kraków, 2008.

Lubamersky L., National self-perception among the Lithuanian nobility: Evidence from the Radziwiłt family, Journal of Baltic Studies, 2001, 32, no. 1, 5-18, DOI: 10.1080/01629770000000211.

Łatyszonek 0., Polityczne aspekty przedstawienia średniowiecznych dziejów ziem białoruskich w historiografii Wielkiego Księstwa Litewskiego XV-XVI w., Białoruskie Zeszyty Historyczne, 2006, 25, 5 -44.

Melville G., Troja. Die integrative Wiege europäischer Mächte im ausgehenden Mittelalter, In: F. Seibt, W. Eberhard (Eds.), Europa 1500. Integrationsprozesse im Widerstreit. Staaten, Regionen, Personenverbände, Christenheit, Klett-Cotta, Stuttgart, 1987, 415-532.

Morawski P., Mit o trojańskim pochodzeniu Franków w historiografii średniowiecznej Francji, Przegląd Humanistyczny, 2007, 51, no. 5, $55-70$.

Niendorf M., Wielkie Księstwo Litewskie. Studia nad kształtowaniem się narodu u progu epoki nowożytnej (1569-1795), trans. M. Grzywacz, Wydawnictwo Poznańskie, Poznań, 2011.

Ochmański J., Nad Kroniką Bychowca, Studia Źródłoznawcze, 1967, 12, 155-163.

Orzeł J., Historia - tradycja - mit w pamięci kulturowej szlachty Rzeczypospolitej w XVI-XVIII wieku, Muzeum Pałacu Króla Jana III w Wilanowie, Warszawa, 2016.

Orzeł J., Lech i Palemon - mityczni założyciele Królestwa Polskiego i Wielkiego Księstwa Litewskiego, In: J. Tazbir, S. Zagórski (Eds.), Z szablą i z kielichem, czyli życie po sarmacku, Oficyna Wydawnicza „Stopka”, Łomża, 2015, 23-39. 
Orzeł J., Poszukiwanie rodowodu Rzeczypospolitej Obojga Narodów przez autora Skarbca rozmaitych sciencyi..., In: W. Walczak, K. Łopatecki (Eds.), Stan badań nad wielokulturowym dziedzictwem dawnej Rzeczypospolitej, vol. 7, Instytut Badań nad Dziedzictwem Kulturowym Europy, Białystok, 2017, 389-414.

Petrauskas R., Dziejopisarstwo a świadomość historyczna, trans. B. Kalęba, In: Kultura Wielkiego Księstwa Litewskiego. Analizy i obrazy, ed. V. Ališauskas [et al.], trans. P. Bukowiec, B. Kalęba, B. Piasecka, Towarzystwo Autorów i Wydawców Prac Naukowych Universitas, Kraków, 2006, 201-213.

Petrauskas R., Europa późnego średniowiecza a rozwój społeczeństwa i kultury Wielkiego Księstwa Litewskiego, Zapiski Historyczne, 2013, 78, no. 3, 39-57.

Petrauskas, Palemon und die vier Sippen: die römische Abstammungstheorie der Litauer, In: S. Donecker (Ed.), Abstammungsmythen und Völkergenealogien im frühneuzeitlichen Ostseeraum, Greifswald [in press].

Pomian K., Francs et Gaulois, In: P. Nora (Ed.), Les Lieux de mémoire, vol. 2, Quarto Gallimard, Paris, 1997, 2245-2300.

Pomian K., Przeszłość jako przedmiot wiary. Historia i filozofia w myśli średniowiecza, $2^{\text {nd }}$ ed., Wydawnictwo Uniwersytetu Warszawskiego, Warszawa, 2009.

Puchowski K., Edukacja historyczna w jezuickich kolegiach Rzeczypospolitej 1565-1773, Wydawnictwo Uniwersytetu Gdańskiego, Gdańsk, 1999.

Richter B.L.O., Trojan or Merovingians? The Renaissance Debate over the Historical Origins of France, In: Mèlanges a la mémoire de Franco Simone, Vol. 4, Slatkine, Geneve, 1983, 111-134.

Semenowicz E., Wokót genealogii Litwinów. U źródeł mitu i sporu historyczno-kulturowego, Studia z Dziejów Rosji i Europy ŚrodkowoWschodniej, 2011, 46, 13-41, DOI: 10.12775/SDR.2011.01.

Semjančuk A., Rolya rymskay legendy y̆ farmavanni dzyarzhay̆nay idealogii Vyalikaga Knyastva Litoy̆skaga, Białoruskie Zeszyty Historyczne, 2002, 18, 178-184.

Suchocki J., Geneza litewskiej legendy etnogenetycznej. Aspekty polityczne i narodowe, Zapiski Historyczne, 1987, 52, no. 1, $27-67$.

Tereškinas E.A., The imperfect body of the community. Identity, discourse and nation in the seventeenth-century Grand Duchy of Lithuania, Lietuviu literaturo sir tautosakos institutas, Vilnius, 2005.

Ulčinaitė E., Literatura neołacińska jako świadectwo litewskiej świadomości państwowej i narodowej, In: J. Axer (Ed.), Łacina w Polsce, part 1-2, Między Slavia Latina i Slavia Orthodoxa, Ośrodek Badań nad Tradycją Antyczną w Polsce i w Europie Środkowo-Wschodniej, Uniwersytet Warszawski, Warszawa, 1995, 27-44.

Vasiliauskas, Antyk i sarmatyzm, trans. B. Kalęba, In: Kultura Wielkiego Księstwa Litewskiego. Analizy i obrazy, ed. V. Ališauskas [et al.], trans. P. Bukowiec, B. Kalęba, B. Piasecka, Towarzystwo Autorów i Wydawców Prac Naukowych Universitas, Kraków, $2006,1-21$.

Venclova T., Mit o początku, trans. R. Śliwowski, Teksty. Teoria Literatury, Krytyka, Interpretacja, 1974, 4, 111-116.

Watson Ch., Tradition and Translation. Maciej Stryjkowski's Polish Chronicle in Seventeenth-Century Russian Manuscripts, Uppsala Universitet, Västerås, 2012.

Wojtkowiak Z., Maciej Stryjkowski, dziejopis Wielkiego Księstwa Litewskiego. Kalendarium życia i działalności, Poznań, Uniwersytet im. Adama Mickiewicza, 1990.

Wulf K., Troja - Metamorphosen eines Mythos. Französische, englische und italienische Überlieferungen des 12. Jahrhunderts im Vergleich, Akademie Verlag, Berlin, 2009.

Zachara-Wawrzyńczyk M., Geneza legendy o rzymskim pochodzeniu Litwinów, Zeszyty Historyczne. Uniwersytet Warszawski, 1963, 3, 5-35. 